\title{
Sulphate sorption by Finnish mineral soils
}

\author{
MARKKU YLI-HALLA \\ Kemira Oy, Espoo Research Centre, Luoteisrinne 2 \\ SF-02270 ESPOO, Finland
}

\begin{abstract}
Sulphate sorption by 38 Finnish cultivated mineral soils was determined and its correlation with soil properties was studied. Sulphate sorption was correlated with soil $\mathrm{pH}\left(\mathrm{r}=-0.46^{* *}\right)$ and with phosphate sorption $\left(\mathrm{r}=0.69^{* * *}\right)$. With increasing soil $\mathrm{pH}$, sulphate sorption decreased in relation to phosphate sorption. Phosphorus status was decisive in explaining the sulphate sorption of the soils. Even if both anions are sorbed by the same soil component (amorphous Al compounds), the sites are not available for sulphate if they are already occupied by phosphate. Sulphate sorption was negligible in soils very rich in easily soluble phosphorus. This was reflected in a close negative correlation between sulphate sorption and acid ammonium acetate $(\mathrm{pH} 4.65)$ extractable phosphorus $\left(\mathrm{r}=-0.70^{* * *}\right)$. During the last few decades, phosphorus fertilization has increased the amount of easily soluble phosphorus in Finnish fields, which obviously has decreased the capacity of the soils to retain sulphate.
\end{abstract}

Index words: sulphate, sorption, soil

\section{Introduction}

Sulphate, the plant-available form of sulphur, enters the soil with wet and dry deposition and fertilizers. Sulphate is also released from soil organic matter. The utilization of these sources of sulphur by plants is partly dependent on the ability of the soil to retain sulphate against leaching. The downward movement of seepage water in autumn and spring is likely to remove poorly sorbed sulphate to a considerable extent from soil pores. On the other hand, plants growing in soils with a strong sulphate sorption tendency probably require less sulphur fertilization.

Recent studies on sulphur sorption have concentrated on coarse forest soils (e.g. SingH 1984, Nodvin et al. 1986). Cultivated soils differ from forest soils e.g. in terms of phosphorus. Cultivated soils are yearly enriched with easily soluble phosphorus compounds. Phosphate and sulphate are known to be sorbed by the same soil components: amorphous $\mathrm{Al}$ and $\mathrm{Fe}$ compounds. The reten- 
tion of phosphate is, however, much stronger than that of sulphate (BARRow 1970). Laboratory experiments on the competition of anions for sorption sites have shown phosphate to reduce sulphate sorption (KAMPRATH et al. 1956, Metson and Blakemore 1978). It has not been established, however, whether the sulphate sorption properties of the soil are influenced by phosphate within normal concentration ranges as opposed to the higher concentrations used in laboratory experiments.

The purpose of this study was to evaluate the ability of Finnish cultivated soils to retain sulphate and the influence of soil properties on the quantities retained. Special attention was paid to the effect of soil phosphorus status on sulphur sorption. The results were to give additional information on the sufficiency of sulphur nutrition of plants in Finland.

\section{Materials and methods}

The soil material consisted of 38 samples collected from the plough layer of cultivated fields in different parts of Finland. The samples were air-dried and ground to pass a $2 \mathrm{~mm}$ sieve. Particle size analysis was done by a pipette method. Organic carbon was determined by a wet digestion method. Soil $\mathrm{pH}$ was measured in a $0.01 \mathrm{M} \mathrm{CaCl}_{2}$ suspension at a soil-solution ratio of 1:2.5 (v/v). Amorphous $\mathrm{Al}$ and $\mathrm{Fe}$ were extracted with $0.05 \mathrm{M}$ am-

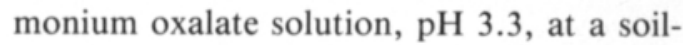
solution ratio of $1: 20(\mathrm{w} / \mathrm{v})$ and shaking time of two hours (HARTIKAINEN 1982). Fe and Al were determined by AAS. The soil properties are presented in Table 1.

Phosphorus, extractable with $0.5 \mathrm{M}$ $\mathrm{CH}_{3} \mathrm{COOH}-0.5 \quad \mathrm{M} \quad \mathrm{CH}_{3} \mathrm{COONH}_{4} \quad(\mathrm{pH}$ 4.65), abbreviated AAAc in this paper, was determined according to VUORINEN and MÄKITIE (1955). Water-soluble phosphorus was determined by the method of HARTIKAINEN (1982). Inorganic phosphorus was fractionated by the CHANG and JACKSON method as modified by HarTIKAINEN (1979). The phosphorus sorption index of the soils was determined by shaking $1.0 \mathrm{~g}$ of soil in $60 \mathrm{ml}$ of solution containing P $0.5 \mathrm{mg} / 1$ as $\mathrm{KH}_{2} \mathrm{PO}_{4}$. Shaking time was 23 hours.

The amount of native sulphur, extracted with $0.01 \mathrm{M} \mathrm{CaCl}_{2}$, was determined by shaking $10 \mathrm{~g}$ of soil in $50 \mathrm{ml}$ of $0.01 \mathrm{M} \mathrm{CaCl}_{2}$ solution for one hour. The extracts were cleared with activated charcoal which does not absorb or release sulphur in the extractant concerned. Sulphur determinations were made using an indirect AAS method proposed by GaLINDO et al. (1969). Adsorption of sulphate was determined by shaking $10 \mathrm{~g}$ of soil in $50 \mathrm{ml}$

Table 1. Chemical characteristics of the experimental soils. Means with the confidence limits at the 95 per cent level.

\begin{tabular}{llccc}
\hline & & $\begin{array}{c}\text { Clay soils } \\
\mathrm{n}=16\end{array}$ & $\begin{array}{c}\text { Silt soils } \\
\mathrm{n}=11\end{array}$ & $\begin{array}{c}\text { Coarse soils } \\
\mathrm{n}=11\end{array}$ \\
\hline Clay \% & mean & $45 \pm 5$ & $19 \pm 6$ & $8 \pm 4$ \\
& range & $30-65$ & $5-29$ & $2-18$ \\
Organic C \% & mean & $3.4 \pm 0.7$ & $3.4 \pm 0.9$ & $3.4 \pm 0.8$ \\
& range & $1.0-7.4$ & $1.5-6.2$ & $1.9-4.6$ \\
pH & mean & $5.1 \pm 0.3$ & $5.2 \pm 0.3$ & $5.6 \pm 0.6$ \\
& range & $4.3-6.5$ & $4.7-6.1$ & $4.0-7.2$ \\
Oxalate-extr. Al & mean & $51 \pm 7$ & $68 \pm 31$ & $86 \pm 36$ \\
mmol/kg & range & $30-89$ & $28-186$ & $27-195$ \\
Oxalate-extr. Fe & mean & $90 \pm 17$ & $63 \pm 10$ & 65 \\
mmol/kg & range & $59-175$ & $43-96$ & 29 \\
\hline
\end{tabular}


of $0.01 \mathrm{M} \mathrm{CaCl}_{2}$ solution which contained $\mathrm{S}$ $20 \mathrm{mg} / \mathrm{l}$ as $\mathrm{K}_{2} \mathrm{SO}_{4}$. The sorption index was calculated from the decrease in concentration during equilibration.

\section{Results}

The amounts of sulphur sorbed, shown in Table 2, ranged from 2 to $32 \%$ mean $19 \%$ of the quantity added. Although the sorption index seemed to be lower in silt soils, the ranges were nearly similar in various textural classes and, thus, the mean sulphur sorption indices did not deviate statistically significantly from one another in various soil groups.

The amounts of sulphur sorbed were of the same magnitude as the quantities of phosphorus retained. One should take into account the fact that the amount of sulphur available for adsorption was $100 \mathrm{mg} / \mathrm{kg}$ and that of phosphorus only $30 \mathrm{mg} / \mathrm{kg}$. Thus, the percentages of phosphorus sorbed were considerably greater than those of sulphur ranging from 31 to $89 \%$, mean as high as $63 \%$.

The relations between sulphate sorption index and soil properties were studied with the correlation analysis. Corresponding calculations were also made for phosphate sorption index. Statistically significant correlation coefficients were as follows: r
S sorption index

$\mathrm{CaCl}_{2}$-soluble

$\mathrm{S}$

Oxalate-

extractable $\mathrm{Al}$

$\mathrm{pH}$

$\mathrm{NH}_{4} \mathrm{~F}-\mathrm{P} / \mathrm{Al}$

$\mathrm{P}$ sorption

index

AAAc-

soluble $\mathrm{P}$

Water-

soluble P
$-0.32^{*}$

n.s.

$-0.46^{* *}$

$-0.62^{* * *}$

$0.69^{* * *}$

$-0.70^{* * *}$

$-0.51^{* * *}$

$-0.68^{* * *}$

$-0.73^{* * *}$
The sulphate sorption index exhibited the highest correlation coefficients with the phosphate sorption index as well as with variables describing the phosphorus status of the soil. The molar ratio of $\mathrm{NH}_{4} \mathrm{~F}$-soluble phosphorus to oxalate-extractable aluminum indicates the degree of phosphate coverage of amorphous aluminum compounds of the soil. This is reflected in the values of water-soluble phosphorus (HaRTIKAINEN 1982) which might be used as an estimate of phosphorus concentration in soil solution (AMARASIRI and OLSEN 1973). In the present material, the same obviously holds also for AAAc-extractable phosphorus.

Table 2. Sulphate and phosphate sorption indices and amounts of $\mathrm{CaCl}_{2}$-extractable sulphur and water-soluble phosphorus in the experimental soils, all expressed as $\mathrm{mg} / \mathrm{kg}$.

\begin{tabular}{lcccc}
\hline & & $\begin{array}{c}\text { Clay soils } \\
\mathrm{n}=16\end{array}$ & $\begin{array}{c}\text { Silt soils } \\
\mathrm{n}=11\end{array}$ & $\begin{array}{c}\text { Coarse soils } \\
\mathrm{n}=11\end{array}$ \\
\hline $\mathrm{CaCl}_{2}$-extractable S & mean & $9.6 \pm 3.0$ & $7.7 \pm 2.3$ & $9.1 \pm 3.7$ \\
& range & $4.5-26.8$ & $2.9-15.8$ & $3.9-20.0$ \\
$\mathrm{~S}$ sorption index & mean & $21.2 \pm 4.8$ & $16.3 \pm 5.7$ & $17.4 \pm 4.9$ \\
& range & $1.7-32.0$ & $6.8-28.4$ & $1.9-30.0$ \\
Water-soluble P & mean & $9.8 \pm 4.0$ & $14.3 \pm 8.3$ & $10.9 \pm 6.1$ \\
& range & $3.1-32.3$ & $3.1-41.2$ & $2.4-24.8$ \\
P sorption index & mean & $19.1 \pm 2.3$ & $17.7 \pm 3.3$ & $19.6 \pm 3.4$ \\
& range & $9.3-24.9$ & $9.5-23.5$ & $13.3-26.7$ \\
\hline
\end{tabular}


The strong correlations mentioned above markedly masked other relationships between the two indices measured and the soil characteristics. Therefore, the partial correlation coefficient was calculated between S sorption (1) and oxalate-extractable $\mathrm{Al}$ (2) so that the effect of $\mathrm{NH}_{4} \mathrm{~F}$-soluble phosphorus (3) was eliminated. This correlation coefficient $\left(r_{12.3}=\right.$ $0.57^{* * *}$ ) proved statistically significant. The corresponding partial correlation coefficient between phosphate sorption index (4) and aluminum $\left(r_{24.3}=0.64^{* * *}\right)$ was also higher than the total one. Partial correlation coefficients remained low between soil $\mathrm{pH}$ and both sorption indices.

It was interesting to observe that oxalateextractable iron and the content of $\mathrm{NaOH}$ extractable phosphorus (»Fe-P») seemed to have no correlation with sulphate or phosphate sorption as far as total or partial correlation coefficients were concerned.

The results were analysed also by the regression analysis. AAAc-extractable phosphorus as $\mathrm{mg} / \mathrm{l}\left(\mathrm{X}_{1}\right)$ explained $49 \%$ of the variation of sulphate sorption (Y). When oxalate-extractable aluminum as $\mathrm{mmol} / \mathrm{kg}$ $\left(\mathrm{X}_{2}\right)$ was added to the regression model, the coefficient of multiple determination increased by $7 \%$. The equation was as follows:

$$
\begin{aligned}
& \mathrm{Y}=0.45 \mathrm{X}_{1}+0.056 \mathrm{X}_{2}+20.44(\mathrm{~F}=22.624 * * *) \\
& \mathrm{R}^{2}=56 \% \\
& \mathrm{~S}=5.73
\end{aligned}
$$

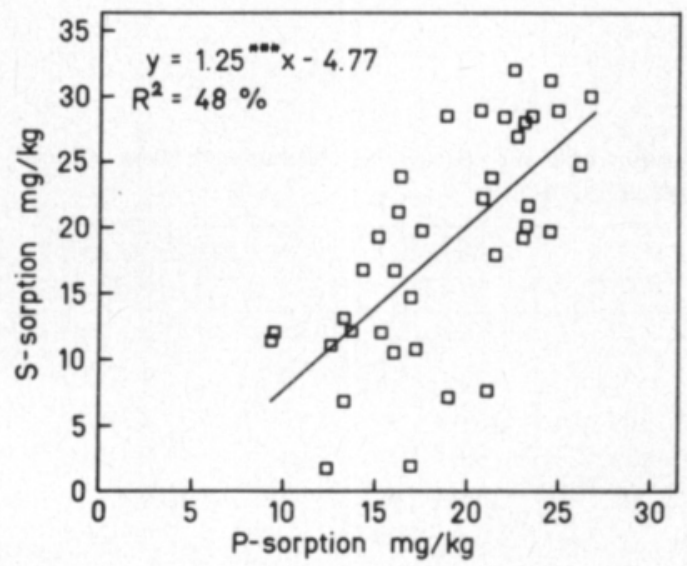

Fig. 1. Dependence of sulphur sorption index on phosphorus sorption index.
In another regression model, the phosphorus sorption index as $\mathrm{mg} / \mathrm{kg}\left(\mathrm{X}_{3}\right)$ alone explained $48 \%$ of the variation of sulphate sorption (Y) (Fig. 1). Inclusion of soil pH $\left(\mathrm{X}_{4}\right)$ in the model increased the coefficient of multiple determination by $14 \%$. The model was as follows:

$$
\begin{aligned}
& \mathrm{Y}=1.15 \mathrm{X}_{3}-4.58 \mathrm{X}_{4}+21.22\left(\mathrm{~F}=27.226^{* * *}\right) \\
& \mathrm{R}^{2}=61 \% \\
& \mathrm{~S}=5.42
\end{aligned}
$$

\section{Discussion}

In the present study, the soil samples displayed great variation in their ability to sorb added sulphate, sorption ranging from nil to more than a third of the amount added. The absolute quantities of sulphate sulphur and phosphate phosphorus sorbed by the samples were rather similar, which apparently differs from the results of BARROw (1970) and SCOTT (1976). One has to take into account two factors which in the present study contributed to the unusually high sorption of sulphate compared to that of phosphate. Firstly, phosphate sorption took place in a soil suspension where no electrolyte was added, while sulphate sorption was determined in a $\mathrm{CaCl}_{2}$-containing environment. Both sulphate and phosphate sorption are known to be enhanced markedly in the presence of neutral salts (e.g. BARRow 1972). Secondly, the concentration of phosphorus in the added solution was only 0.5 $\mathrm{mg} / \mathrm{l}$, or forty times less than that of sulphur in the corresponding solution, $20 \mathrm{mg} / \mathrm{l}$. The quantities of a certain ion sorbed are usually the greater, the higher the concentration in the solution added (e.g. KAMPrATH et al. 1956, RAJAN 1974, 1978). The absolute sorption index values, depending greatly on the test conditions, are thus of minor importance. Attention is to be paid rather on their correlation with soil properties. Some significant observations can be made, even though the variation in the sulphate sorption index could only partly be explained by the soil properties.

In the soils used in this study, the abundance of oxalate-extractable aluminum seemed to 
control sulphate sorption, as has been reported also by BArrow (1967) in Australian soils. In Scottish soils, amorphous iron was considered at least as responsible for sulphate sorption as aluminum (Scotr 1976). This disagreement can be due to the difference in the $\mathrm{pH}$ in which sorption was measured. ScoTT

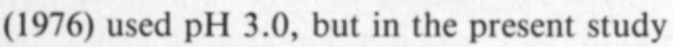
the determinations were made in unbuffered suspensions where $\mathrm{pH}$ ranged from 4.0 to 7.2.

Hartikainen (1981) has suggested a theory which tends to explain why Fe compounds, as compared to $\mathrm{Al}$ compounds, are relatively less important sorbents for phosphate at normal soil $\mathrm{pH}$ than at very low $\mathrm{pH}$. This theory is also applicable to sulphate sorption. The theory is based on the fact that iron is a harder Lewis acid than aluminum. Consequently, at a certain $\mathrm{pH}$, there are more $\mathrm{H}_{2} \mathrm{O}$ ligands coordinated with $\mathrm{Al}$ than with $\mathrm{Fe}$ which is correspondingly greatly surrounded by hydroxyls. Water ligands are more easily displaced by sulphate than hydroxyls (RAJAN 1978), and therefore $\mathrm{Al}$ compounds offer in Finnish soils within normal $\mathrm{pH}$ range more easily accessible sites for sorption of sulphate than do Fe compounds as was observed in the present study. At $\mathrm{pH} 3.0$ also $\mathrm{Fe}$ is mainly coordinated with water ligands and, thus, $\mathrm{Fe}$ compounds may well serve as important sorbents for sulphate at this exceptionally low $\mathrm{pH}$ as was demonstrated by ScOTT (1976).

Elevation in soil $\mathrm{pH}$ also affects sulphate sorption more directly. With rising $\mathrm{pH}$ the concentration of hydroxyls in the soil suspension increases and sulphate sorption decreases due to anion competition (KAMPRATH et al. 1956), the net negative charge of the soil also increases, and the surfaces begin to exercise electrical repulsion on sulphate, leading to declining sorption of sulphate (ScOTт 1976). Actually, BARRow (1970) has pointed out that sorption of sulphate decreases more than that of phosphate with increasing $\mathrm{pH}$. This net ef- fect of soil $\mathrm{pH}$ on the sulphate sorption was also seen in the present study.

Phosphorus status of the experimental soils, practically covering the whole range found in Finland (KURKI 1982), seemed to affect, in addition to phosphate sorption, decisively also sulphate sorption in the soil. Soils low in easily soluble phosphorus sorbed the largest amounts of sulphur. On the other hand, in soils rich in easily soluble phosphorus, sulphur sorption was reduced as the sorption sites were already occupied by phosphorus. In earlier studies, KAMPrATH et al. (1956) and METSON and BLAKEMORE (1978) have shown that phosphate can prevent sulphate sorption. In those experiments, the quantities of phosphorus added were at least several hundred milligrams per kilogram of soil. METSON and BLAKEMORE (1978) equilibrated the soil samples in a solution which contained $500 \mathrm{ppm}$ $\mathrm{P}$ and 500 or $1500 \mathrm{ppm} \mathrm{S}$. These concentrations inevitably produce extracts very different from the soil solution, where phosphorus concentration seldom exceeds $1 \mathrm{mg} / 1$ (e.g. MENGEL et al. 1968, WiKLANDER and ANDERSSON 1974). In the present study, it was shown that phosphate levels met in ordinary cultivated soils may reduce sulphate sorption as well. The sorption capacity of sulphate was, however, negligible only in soils unusually rich in easily soluble phosphorus.

According to KURKI (1982), the average content of AAAc-extractable phosphorus has increased in Finnish fields due to fertilization, from about $4 \mathrm{mg} / \mathrm{l}$ to $11 \mathrm{mg} / \mathrm{l}$ in less than three decades. The frequency of very high phosphorus contents has necessarily increased, too. The observations of the present study suggest that the capacity of Finnish field soils, at least in the plough layer, to sorb sulphate has diminished accordingly.

Acknowledgement. The author wishes to thank the August Johannes and Aino Tiura Agricultural Research Foundation for the financial support of this study. 


\section{References}

Amarasiri, S.L. \& Olsen, S.R. 1973. Liming as related to solubility of $\mathrm{P}$ and plant growth in acid tropical soil. Soil Sci. Soc. Amer. Proc. 37: 716-721.

Barrow, N.J. 1967. Studies on the adsorption of sulfate by soils. Soil Sci. 104: 342-349.

,- 1970 . Comparison of the adsorption of molybdate, sulfate and phosphate by soils. Soil Sci. 109: 282-288.

,- 1972 . Influence of solution concentration of calcium on the adsorption of phosphate, sulfate and molybdate by soils. Soil Sci. 113: 175-180.

Galindo, G.G., Appelt, H. \& Schalscha, E.B. 1969. Sulfur determination in soil extract by an indirect atomic absorption spectrophotometric method. Soil Sci. Soc. Amer. Proc. 33: 974-975.

Hartikainen, H. 1979. Phosphorus and its reactions in terrestrial soils and lake sediments. J. Scient. Agric. Soc. Finl. 51: 537-624.

-, 1981. Effect of decreasing acidity on the extractability of inorganic soil phosphorus. J. Scient. Agric. Soc. Finl. 53: $16-26$.

,- 1982 . Water soluble phosphorus in Finnish mineral soils and its dependence on soil properties. J. Scient. Agric. Soc. Finl. 54: 89-98.

Kamprath, E.J., Nelson, W.L. \& Fitts, J.W. 1956. The effect of $\mathrm{pH}$, sulfate and phosphate concentration on the adsorption of sulfate in soils. Soil Sci. Soc. Amer. Proc. 20: 463-466.

KURKı, M. 1982. Suomen peltojen viljavuudesta. III. Summary: On the fertility of Finnish tilled fields in the light of investigations of soil fertility carried out in the years 1955-1980. 181 p. Helsinki.

Mengel, K., Grimme, H. \& Nemeth, K. 1969. Potentielle und effektive Verfügbarkeit von Pflanzennăhrstoffen in Boden. Landw. Forsch. 23/I Sonderheft: 79-91.

Metson, A.J. \& Blakemore, L.C. 1978. Sulphate retention by New Zealand soils in relation to the competitive effect of phosphate. N.Z. J. Agric. Res. 21: 243-253.

Nodvin, S.C., Driscoll, C.T. \& Likens, G.E. 1986. The effect of $\mathrm{pH}$ on sulfate adsorption by a forest soil. Soil Sci. 142: 69-75.

RAJAN, S.S.S. 1978. Sulfate adsorbed on hydrous alumina, ligands displaced, and changes in surface charge. Soil Sci. Soc. Amer. Proc. 42: 39-44.

-, Perrot, K.W. \& Saunders, W.M.H. 1974. Identification of phosphate-reactive sites of hydrous alumina from proton consumption during phosphate adsorption at constant $\mathrm{pH}$ values. J. Soil Sci. 25: 438-447.

Scotr, N.M. 1976. Sulphate contents and sorption in Scottish soils. J. Sci. Fd. Agric. 27: 367-372.

SiNGH, B.R. 1984. Sulfate sorption by acid forest soils: 1. Sulfate adsorption isotherms and comparison of different adsorption equations in describing sulfate adsorption. Soil Sci. 138: 189-197.

Vuorinen, M. \& Mä́ıтıe, O. 1955. The method of soil testing in use in Finland. Agrogeol. Publ. 63: 1-44.

Wiklander, L. \& Andersson, A. 1974. The composition of the soil solution as influenced by fertilization and nutrient uptake. Geoderma 11: 157-166.

Ms received February 2, 1987.

\section{SELOSTUS}

\section{Suomalaisten kivennäismaiden sulfaatinpidätyskyky}

\section{Markku Yli-Halla}

\section{Kemira Oy, Espoon tutkimuskeskus Luoteisrinne 2, 02270 Espoo}

Sulfaatin pidăttymistă kivennăismaihin tutkittiin 38 muokkauskerroksesta otetun maanăytteen aineistolla. Pidăttyneet sulfaattirikkimăărăt suurenivat maan $\mathrm{pH}: \mathrm{n}$ aletessa $\left(r=-0.46^{* * *}\right)$ ja maan fosforinpidătyskyvyn kasvaessa $\left(r=0.69^{* * *}\right)$. Mită enemmän maassa oli happamaan ammoniumasetaattiin ( $\mathrm{pH} 4.65$ ) uuttuvaa fosforia, sitä vähemmän maa pidătti sulfaattirikkiä $\left(\mathrm{r}=-0.70^{* * *}\right)$. Amorfiset alumiiniyhdisteet, jotka ensisijaisesti säätelevăt helppoliukoisen fosforin maaăräă maassa, ovat myős tärkein sulfaattia sitova ainesosa. Jos maan alumiiniyhdisteiden anioninpidătyspaikat ovat suureksi osaksi fosfaatin miehittămăt, voi maa pidăttăă vain niukasti sulfaattia, joka sitoutuu maahan paljon heikommin kuin fosfaatti. Viime vuosikymmenină peltojemme muokkauskerroksen helppoliukoisen fosforin varat ovat kasvaneet tuntuvasti, mikă on ilmeisesti pienentănyt maittemme sulfaatinpidätyskykyä. 